\title{
Long term study of the effect of sodium cromoglycate on non-specific bronchial hyperresponsiveness
}

\author{
CHRISTINE J JENKINS, ANTONY B X BRESLIN
}

From the Respiratory Unit, Concord Hospital, Sydney, New South Wales, Australia

ABSTRACT A double blind, crossover study was undertaken to determine whether non-specifiE⿱ hyperresponsiveness in subjects with asthma was reduced by long term treatment with sodiunis cromoglycate and, if so, whether this was related to change in lung function. Forty four adulf asthmatic subjects (41 atopic, three non-atopic) entered the one year study at intervals staggeree over six months. After a baseline period to ensure that asthma control was stable subjects entered the treatment period, during which they inhaled sodium cromoglycate $20 \mathrm{mg}$ four times daily of matching placebo four times daily for 16 weeks each, in random order. Response was assessed a $\vec{\Phi}$ four weekly intervals by measurement of lung function and histamine inhalation tests, from whice the provocative concentration of histamine causing a $20 \%$ fall in $\mathrm{FEV}_{1}\left(\mathrm{PC}_{20} \mathrm{H}\right)$ was calculated. The assessment included daily symptom score, morning and evening Airflometer readings an $\Phi_{\infty}$ treatment; mean values for each treatment period and also for the final four weeks of each period were compared. There were no significant differences between placebo and sodium cromoglycat treatment for $\mathrm{PC}_{20} \mathrm{H}, \mathrm{FEV}_{1}$, morning or evening flow meter readings, bronchodilator usage, of symptom scores for the group as a whole, for the 16 week period or for the final four weeks of eact period. Thirteen subjects showed better morning and evening flow meter readings while taking sodium cromoglycate than while taking placebo and eight better readings with placebo than with sodium cromoglycate $(p<0.05)$. Improvement in lung function did not correlate with baseline lung $\vec{g}$ function or baseline $\mathrm{PC}_{20} \mathrm{H}$, or with features of atopy. These results suggest that long term sodium cromoglycate treatment does not alter non-specific bronchial responsiveness in adult asthmatie subjects.

Many drugs used for the symptomatic treatment of asthma have been shown in short term or single dose studies to modify both specific and non-specific airway hyperresponsiveness. ${ }^{1-4}$ This effect is seen acutely with $\beta_{2}$ adrenoceptor agonists, ${ }^{3-7}$, which nevertheless have not been shown to reduce airway responsiveness to histamine over a four week period. ${ }^{4}$ Two non-bronchodilator agents, inhaled sodium cromoglycate ${ }^{8-11}$ and inhaled corticosteroids, ${ }^{12}$ have been reported to reduce non-specific airway hyperresponsiveness over longer periods of time. When the present study began no double blind, placebo controlled study examining the long term effect of sodium cromoglycate on airway hyperresponsiveness had been performed. While some

Address for reprint requests: Dr C J Jenkins, Respiratory Unit, Concord Hospital, Concord, New South Wales 2139, Australia.

Accepted 25 November 1986 circumstantial evidence, combined with a theoretical understanding of the drug's mode of action, ${ }^{13-1 ;}$ suggested that sodium cromoglycate could reduce non-specific hyperresponsiveness, most of the dat 8 supported this hypothesis only indirectly. ${ }^{8916-1 \frac{9}{2}}$ Most single and multiple dose studies of the effect of sodium cromoglycate on histamine hypers responsiveness have not shown any appreciab protection. ${ }^{19-21}$ Two more recent double blind, placebo controlled studies ${ }^{1022}$ failed to find $\mathscr{a}$ significant change in bronchial responsiveness to methacholine or histamine after treatment witto sodium cromoglycate for two weeks.

Our study was undertaken to examine thes hypothesis that long term administration of sodiurf cromoglycate could reduce non-specific bronchial hyperresponsiveness in subjects with chronic asthmao The relationship between change in airwa obstruction and change in responsiveness was also examined to determine whether any observed effe 8 was dependent on change in lung function. 


\section{Methods}

\section{SUBJECTS}

Forty eight subjects with asthma (as defined by the American Thoracic Society ${ }^{23}$ ) entered the study. Twenty were male and 28 female, their ages ranging from 15 to 65 (mean 37) years. Twenty patients had first developed asthma before they were 10, and 11 at the age of 40 or more. All were non-smokers, although eight had smoked previously. Mean FEV was 2.271 ( $72 \%$ predicted, range $37-103 \%$ predicted). The geometric mean $\mathrm{PC}_{20} \mathrm{H}$ was 0.37 (range 0.05-5.66) $\mathrm{mg} / \mathrm{ml}$. Most subjects had moderate asthma with symptoms requiring more than one form of treatment for control. Further clinical and lung function details are given in table 1.

\section{STUDY DESIGN}

The study was of double blind, randomised, placebo controlled crossover design. Subjects entered the trial at intervals staggered over six months, beginning in March, and the trial lasted one year for each subject. This year was divided into a baseline period ( 8 weeks), two treatment periods (each 16 weeks) and a washout period (12 weeks). Visits were made to the respiratory laboratory for review by the investigator and for lung function tests at $0,4,8,14,20,24,30,36,40,46$, and 52 weeks, as shown below.

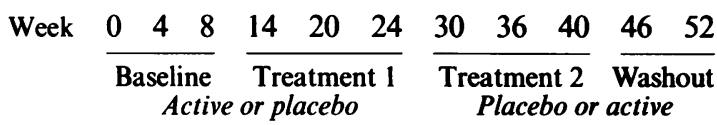

At the first visit a modified Brompton Hospital respiratory questionnaire was administered and skinprick testing with 26 common allergens performed. Blood was taken for a full blood count, determination of serum IgE levels, and testing for Aspergillus precipitins. Patients were instructed in the use of the diary card and taught to use the Airflometer, ${ }^{24}$ a portable instrument used for monitoring lung function at home. The readings (in

Table 1 Clinical details of 48 subjects with asthma

\begin{tabular}{ll}
\hline Sex (M:F) & $20: 28$ \\
Age (y): mean (SD) & $36 \cdot 5(16 \cdot 1)$ \\
Age (y) at onset: mean (SD) & $19 \cdot 1(18 \cdot 8)$ \\
Number with positive SPT & 41 \\
FEV ${ }_{1}(\%$ pred): mean (SD) & $71 \cdot 9(18 \cdot 6)$ \\
PC $_{20}$ H (mg/ml): mean & $0 \cdot 37$ \\
FEV $($ (l): mean (SD) & $2 \cdot 27(0 \cdot 80)$ \\
No of patients having baseline treatment with: & 9 \\
salbutamol only & 97 \\
salbutamol and beclomethasone & 19 \\
salbutamol, beclomethasone, theophylline & 3 \\
salbutamol and theophylline & 19 \\
\hline
\end{tabular}

SPT - skinprick test reactions (positive if $>2 \mathrm{~mm}$ weal in response to one or more of 26 common allergens); FEV $_{1}$ - forced expiratory volume in one second; $\mathrm{PC}_{20} \mathrm{H}$-provocative concentration of histamine causing a $20 \%$ fall in $\mathrm{FEV}_{1}$.
AFM units), have been shown to reflect both expiratory flow rate and total expired volume (FVC). At this visit patients also gave informed written consent to the protocol, which had been approved by the hospital ethics committee. Lung function studies and a histamine inhalation test (HIT) were performed at this and all subsequent visits to the laboratory. At subsequent visits diary cards were reviewed and collected, and a diary card was issued for the next four weeks.

At week 8 patients were issued with their trial treatment for the following 16 weeks (treatment 1). Subjects were randomly assigned to receive active drug or placebo during treatment period 1 and were issued with eight canisters, each with two weeks' supply of capsules. They were instructed to inhale one capsule from a Spinhaler (Fisons) four times daily. The active and placebo capsules were identical in appearance, although the active drug (sodium cromoglycate $20 \mathrm{mg}$ plus lactose $20 \mathrm{mg}$-Spincaps, Fisons) and placebo (lactose $20 \mathrm{mg}$ ) differed slightly in taste. At week 24 all unused treatment was returned and patients were issued with a new box of capsules (treatment 2) and a new Spinhaler.

While some rationalisation of the treatment took place during the baseline period, prescribed asthma treatment was not altered subsequently unless uncontrolled symptoms of asthma necessitated the addition of oral corticosteroids. This occurred in seven subjects. Patients were encouraged to reduce or increase their use of inhaled $\beta_{2}$ agonists if their symptoms warranted it and instructed to note all details of change in treatment in the diary card.

\section{LUNG FUNCTION AND HISTAMINE INHALATION} TESTS

All lung function tests were performed in an air conditioned laboratory, at the same time of day for each subject. Lung volume measurements, by helium dilution (Collins lung volume module), included vital capacity (VC), functional residual capacity (FRC), residual volume (RV), and total lung capacity (TLC). Spirometry was performed with a water sealed Godart spirometer. Patients were instructed not to take inhaled $\beta_{2}$ agonists, beclomethasone dipropionate, or sodium cromoglycate for six hours, or theophylline for 24 hours, before each appointment.

The histamine inhalation test was performed with a Rosenthal-French Dosimeter and de Vilbiss nebuliser (No 646) according to the method of Chai $e^{2} a^{25}$ and the dose response curve was constructed according to the method of Cockcroft et al. ${ }^{26}$ Briefly, aerosol was inhaled at five minute intervals by taking five breaths from the nebuliser, beginning with phosphate buffered saline (control) and followed by phosphate buffered histamine administered in doubling incre- 
ments from $0.03 \mathrm{mg} / \mathrm{ml}$ to a maximum of $16 \mathrm{mg} / \mathrm{ml}$. Response was measured by change in forced expiratory volume in one second $\left(\mathrm{FEV}_{1}\right)$ at 30 and 90 seconds after the last inhalation, and the test was

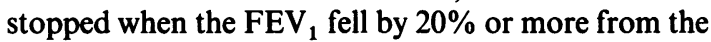
lowest post saline value. The dose-response curve was constructed and the result expressed (in $\mathrm{mg} / \mathrm{ml}$ ) as the provocative concentration of histamine causing a $20 \%$ fall in $\mathrm{FEV}_{1}\left(\mathrm{PC}_{20} \mathrm{H}\right)$.

\section{DIARY CARDS}

Each patient kept a daily record of symptoms, treatment, and morning and evening Airflometer readings, for which careful instruction and supervision were given. Patients recorded the best of three readings, morning and evening, taken before bronchodilator. Symptoms (day and night asthma, cough, and sputum) were graded in severity from 1 to 4 (none to severe), and all treatment, including the number of trial capsules taken, was recorded daily.

\section{STATISTICAL ANALYSIS}

To compare treatment responses to sodium cromoglycate and to placebo, the data for all $\mathbf{4 0}$ subjects were pooled for analysis, and the Student's paired $t$ test and Wilcoxon rank sum analysis were used. Values for all lung function and histamine inhalation test measurements were taken from each visit and the mean for each treatment period was compared. In addition, the last four weeks of each treatment period were compared. Mean weekly values from the diary card (symptom score, morning and evening flow meter readings, and treatment usage) were calculated. The mean value for all 16 weeks and for the last four weeks were compared for each treatment period. Paired $t$ tests were also used to test for a treatment effect between the groups receiving sodium cromoglycate and placebo as initial treatment. All $\mathrm{PC}_{20} \mathrm{H}$ values were logarithmically transformed. Change in $\mathrm{PC}_{20} \mathrm{H}$ was assessed by comparing the $\mathrm{PC}_{20} \mathrm{H}$ fold change $\left(\mathrm{PC}_{20} \mathrm{H}\right.$ after treatment: $\mathrm{PC}_{20} \mathrm{H}$ before treatment) before and at the end of each treatment period. Subgroup analysis tests) were also performed to compare pollen sensitive subjects receiving sodium cromoglycate with thos receiving placebo in the spring, and also subjects treated with sodium cromoglycate in Spring with those treated later in the year, in an attempt $\vec{\theta}$ determine whether seasonal factors were important.

\section{Results}

Forty eight patients with asthma were admitted to thị̂ study and 40 were able to complete it. Three subjects dropped out during the baseline period (one throug unrelated illness, two because of inability to attend the laboratory) and a further five subjects (three having placebo and two sodium cromoglycate) at the end of treatment 1 (one having cromoglycate, becaus of moderately severe asthma requiring frequeid courses of oral corticosteroids and admission hospital, and two due to inability to continus attending the laboratory).

Although subjects were randomly allocated receive placebo or sodium cromoglycate first the resulting groups differed $(\mathrm{p}<0.05)$ with respect age at entry into the study (mean 33 (SEM 3) years for cromoglycate $v 45$ (3) years for placebo) and age onset of asthma (14.4 (3) years for cromoglycate $v$ (5) years for placebo). None of the other clinical ang lung function indices differed significantly betwee the two groups.

For the group as a whole there was no significa䧺 difference between placebo and active treatment periods for lung function or symptoms (FEV morning and evening flow meter readings, sympto score, lung volumes) or for $\mathrm{PC}_{20} \mathrm{H}$ values (see tables: 2 and 3). This was true both for the total treatme period and for the last four weeks of each period, and was also true when non-parametric analysis was usec Significantly fewer subjects took prednisone during the cromoglycate period than during the placebo period $(3 \vee 7)$ but no other measure of response (lur function, $\beta_{2}$ agonist use, or symptom score) differed

Table 2 Group means and 95\% confidence limits for four study periods: results of lung function tests

\begin{tabular}{|c|c|c|c|c|}
\hline & Base & $S C G$ & Placebo & Washout \\
\hline $\begin{array}{l}\mathrm{FEV}_{1}(1) \\
\mathrm{FEV}_{1} \% \mathrm{P} \\
\mathrm{PC}_{20} \mathrm{H}(\mathrm{mg} / \mathrm{ml}) \\
\mathrm{PC}_{20} \mathrm{H}(\mathrm{mg} / \mathrm{ml}) \text { excluding URTI } \\
\mathrm{PC}_{20} \mathrm{H}(\mathrm{mg} / \mathrm{ml}) \text { SCG first } \\
\mathrm{PC}_{20} \mathrm{H} \text { placebo first } \\
\mathrm{PC}_{20} \mathrm{H}(\mathrm{mg} / \mathrm{ml}) \text { whole group, last } 4 \text { weeks } \\
\mathrm{PC}_{20} \mathrm{H} \mathrm{(mg/ml)} \text { last } 4 \text { weeks, excluding URTI } \\
\mathrm{PC}_{20} \mathrm{H}(\mathrm{mg} / \mathrm{ml}) \text { lung function responders }\end{array}$ & $\begin{array}{l}2.3(\text { SD 0.7) } \\
72.8(\text { SD 16.3) } \\
0.44(0.06-3.4) \\
0.44(0.06-4.7) \\
0.39(0.08-1.95) \\
0.52(0.04-6.5) \\
\\
0.42(0.04-4.27)\end{array}$ & $\begin{array}{l}2.3(\text { SD } 0.7) \\
73.4(\text { SD } 14.5) \\
0.62(0.12-3 \cdot 18) \\
0.60(0.17-3.10) \\
0.64(0.16-2.47 \\
0.63(0.09-4.48) \\
0.54(0.04-6.7) \\
0.50(0.40-6.1) \\
0.67(0.07-6.6)\end{array}$ & $\begin{array}{l}2.3(\text { SD } 0.8) \\
72.3(\text { SD 16.5) } \\
0.66(0.09-4.8) \\
0.66(0.10-4.5) \\
0.49(0.07-3.5) \\
0.98(0.16-5.94) \\
0.58(0.07-5 \cdot 1) \\
0.62(0.13-2.9) \\
0.62(0.06-6.1)\end{array}$ & 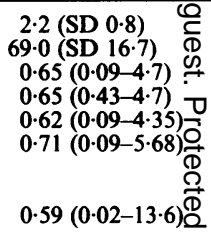 \\
\hline
\end{tabular}

$\mathrm{FEV}_{1}$ - forced expiratory volume in one second; $\mathrm{PC}_{20} \mathrm{H}-$ provocative concentration of histamine causing a $20 \%$ fall in $\mathrm{FEV} ; \mathrm{SCG}-$ sodi cromoglycate; $\% \mathrm{P}$-value expressed as a $\%$ of the predicted normal for sex, age, and height; URTI-upper respiratory tract infection. 
Table 3 Group mean values (with standard deviations in parentheses) for the four study periods: diary card

\begin{tabular}{|c|c|c|c|c|}
\hline & Base & $S C G$ & Placebo & Washout \\
\hline Symptom score & $39.46(8.09)$ & $35.81(8.42)$ & $35.69(7.23)$ & $36 \cdot 53(9 \cdot 30)$ \\
\hline Morning AFM (daily mean) & $56.49(37.72)$ & $63.43(43.09)$ & $68 \cdot 81(43 \cdot 27)$ & $62.22(44.05)$ \\
\hline Evening AFM (daily mean) & $65.43(39 \cdot 12)$ & $72 \cdot 18(44 \cdot 48)$ & $75.09(43.13)$ & $69 \cdot 87(43.39)$ \\
\hline Inhaled bronchodilator (puffs/week) & $57.39(28.0)$ & $57.30(29.88)$ & $54.93(30.54)$ & $60.60(29.70)$ \\
\hline Oral corticosteroids (mg/week) & $18.70(13.69)^{*}$ & $6.88(2 \cdot 71) \dagger$ & $33.08(36 \cdot 37) \ddagger$ & $14.92(7.90)^{*}$ \\
\hline Inhaled corticosteroids (puffs/week) & $62.53(26.53)$ & $57.94(26.89)$ & $62.93(27.35)$ & $66 \cdot 34(25 \cdot 70)$ \\
\hline Theophylline (mg/week) & $351.4(177.0)$ & $368 \cdot 0(179 \cdot 3)$ & $409.44(166 \cdot 8)$ & $388.97(182.7)$ \\
\hline
\end{tabular}

*7 subjects $\{$ Dose $(\mathrm{mg} /$ week) of oral corticosteroids is expressed as a mean for the number of subjects who took oral corticosteroids

$\left.\begin{array}{l}+3 \text { subjects } \\ \ddagger 6 \text { subjects }\end{array}\right\} \begin{aligned} & \text { Dose }(\mathrm{mg} / \text { week }) \text { of } \\ & \text { during each period. }\end{aligned}$

AFM-airflow meter readings; SCG-sodium cromoglycate.

significantly between cromoglycate and placebo periods either for the whole period or for the last four weeks of each period.

Forty one episodes of upper respiratory tract infections occurred in 33 subjects during the year. Nine of these occurred outside either treatment period and 12 were during sodium cromoglycate and 10 during placebo treatment. When all $\mathrm{PC}_{20} \mathrm{H}$ values recorded within six weeks of an upper respiratory tract infection were excluded, there was no difference between cromoglycate and placebo $\mathrm{PC}_{20} \mathrm{H}$ values for the whole period or for the last four weeks only. When the $\mathrm{PC}_{20} \mathrm{H}$ data on pollen sensitive subjects treated in spring were analysed separately the mean fold change in $\mathrm{PC}_{20} \mathrm{H}$ over the months August-November (peak pollen count) did not differ significantly between subjects taking sodium cromoglycate (1.4) and those taking placebo (1.9).

Individual changes in lung function were assessed by comparing $t$ score differences for each subject between active and placebo treatment periods. Thirteen subjects showed a significant $(p<0.05)$ improvement in morning and evening AFM while taking sodium cromoglycate, the mean morning flow meter reading being 66 (SD 53) for cromoglycate and 57 (44) for placebo. The mean $\mathrm{FEV}_{1} \%$ predicted for these subjects was 71 (16) for cromoglycate and 64 (17) for placebo. The mean $\mathrm{PD}_{20} \mathrm{H}$ did not, however, differ significantly between cromoglycate and placebo periods, the mean values with $95 \%$ confidence limits being $0.67(0.07-6.6)$ and $0.62 \quad(0.06-6.1) \mathrm{mg} / \mathrm{ml}$ respectively. Eight subjects had significantly better morning and evening flow meter readings during placebo than during cromoglycate periods. Several clinical indices were used to examine the possible differences between responders to cromoglycate and non-responders (table 4). The only significant difference was in age of onset of asthma, which was 15 (SD 4) years for responders and 24 (4) years non-responders $(p<0.01)$.
Table 4 Baseline characteristics of responders and non-responders (means with standard deviations in parentheses)

\begin{tabular}{lcc}
\hline & Non-responders & Responders \\
\hline No of subjects & 27 & 13 \\
Age (years) & $35 \cdot 7(18 \cdot 4)$ & $43 \cdot 5(11 \cdot 4)$ \\
Age of onset (years) & $24 \cdot 3(20 \cdot 7)^{*}$ & $15 \cdot 2(17 \cdot 1)^{*}$ \\
FEV $(\%$ predicted) & $70 \cdot 7(17 \cdot 3)$ & $67 \cdot 1(17 \cdot 1)$ \\
IgE $(\mathrm{U} / \mathrm{ml})$ & $397 \cdot 5(507 \cdot 3)$ & $452 \cdot 2(455 \cdot 3)$ \\
Blood eosinophils (n/mm) & $609 \cdot 9(398 \cdot 8)$ & $443 \cdot 7(393 \cdot 7)$ \\
No of positive SPT & $8 \cdot 3(5 \cdot 3)$ & $9 \cdot 2(5 \cdot 9)$ \\
PC $_{20} \mathrm{H}(\mathrm{mg} / \mathrm{ml})$ & $0 \cdot 44(2 \cdot 95)$ & $0 \cdot 37(2 \cdot 66)$ \\
\hline
\end{tabular}

$* \mathrm{p}<0.01$.

SPT-skinprick test reactions (positive if $>2 \mathrm{~mm}$ weal in response to one or more of 26 common allergens).

\section{Discussion}

The findings of this study suggest that the administration of sodium cromoglycate to adults with asthma does not alter non-specific bronchial hyperresponsiveness during 16 weeks, a period in which therapeutic benefit could be expected to be seen. Improvement in lung function occurred in 13 of the 48 subjects, but even this group showed no difference in $\mathrm{PC}_{20} \mathrm{H}$ values between cromoglycate and placebo periods. The results concur with those of studies conducted over shorter periods, which have shown attenuation of the airway response to specific stimuli, such as allergen and cold air, but not to histamine or methacholine. ${ }^{102027}$

The well established efficacy of sodium cromoglycate in the context of specific bronchial provocations, such as exercise, ${ }^{28}$ allergen, ${ }^{11} 19$ and cold air, ${ }^{27}$ along with its usefulness as a prophylactic agent in asthma, ${ }^{111718}$ has led to the speculation that it may reduce non-specific bronchial hyperresponsiveness. Data suggesting that long term administration of cromoglycate could reduce non-specific bronchial hyperresponsiveness first came from Altounyan in $1970,{ }^{8}$ who documented a reduction in histamine responsiveness after two weeks' treatment 
with the drug in one individual during the pollen season. Subsequently, Altounyan documented a similar reduction in histamine responsiveness in 10 subjects during the pollen season, despite no change in baseline $\mathrm{FEV}_{1} \cdot{ }^{811}$ This effect probably results from prevention of the allergic reaction during the pollen season, which thus inhibits an allergen induced increase in non-specific bronchial responsiveness. ${ }^{29}$

Dickson $^{9}$ has reported a one year trial of a combination of sodium cromoglycate and isoprenaline in 24 asthmatic children. The percentage fall in $\mathrm{FEV}_{1}$ in response to a single dose of histamine was less while they were taking sodium cromoglycate-isoprenaline than three to seven days after withdrawal. The study was neither blind nor placebo controlled, however, and possibly the $\beta$ agonist was contributing to this effect. Silverman ${ }^{18}$ could not detect any change in histamine responsiveness in a year long, placebo controlled and double blind, parallel study of cromoglycateisoprenaline compound in 53 asthmatic children. Of four more recent studies examining the effect of cromoglycate on non-specific responsiveness, three have not shown any benefit, ${ }^{11022}$ while one found an increase in $\mathrm{PC}_{20} \mathrm{H}$ over six weeks, though the magnitude of the change was not stated. ${ }^{30}$ The weight of evidence therefore indicates a role for cromoglycate in preventing the consequences of natural allergen exposure and of modifying the airway response to specific stimuli such as exercise and cold air, but does not confirm a direct effect in reducing non-specific responsiveness.

For the subgroup whose lung function improved with sodium cromoglycate there was no association between an improvement in lung function and a reduction in non-specific responsiveness as measured by $\mathrm{PC}_{20} \mathrm{H}$. There was no difference in mean $\mathrm{PC}_{20} \mathrm{H}$ values between those who improved in lung function and those who did not, suggesting that baseline non-specific responsiveness is not a determinant of the therapeutic response to cromoglycate.

Although the results from this study concur with those from several single dose and short term studies, other possible reasons for a lack of change in $\mathrm{PC}_{20} \mathrm{H}$ should be considered. Firstly, while $\mathrm{PC}_{20} \mathrm{H}$ is highly reproducible over short periods, ${ }^{31}$ it is probably less reproducible over weeks and months. ${ }^{32}$ Detecting a significant change in non-specific responsiveness is therefore more difficult in studies of several months than in short term studies. In addition, using a drug that does not usually benefit all patients introduces the problem of a varying response, militating against a statistically significant change in $\mathrm{PC}_{20} \mathrm{H}$ for the whole group.

One of the aims of the staggered entry into the study over a six month period was to dilute any seasonal effect. More pollen sensitive subjects took $\overrightarrow{\vec{p}}$ sodium cromoglycate than placebo in spring be chance. The change in $\mathrm{PC}_{20} \mathrm{H}$ for this subgroup wa옹 no different from that of the pollen sensitive subjects taking placebo in spring, so allergen exposure seem $\$$ an unlikely explanation for a lack of improvement ing non-specific responsiveness in these subjects. Very few subjects were sensitive only to pollen, and for mos? common inhaled allergens exposure is year round in Sydney.

Ideally, to examine the effect of sodiun cromoglycate on non-specific responsiveness, subjects having minimal asthma treatment would be mosto suitable, minimising treatment interaction as well ag the fluctuations in lung function that occur in more severely affected subjects. Beclomethasone has beep reported to reduce non-specific responsiveness, ${ }^{12}$ and may reduce the potential therefore for a furthefs increase in $\mathrm{PC}_{20} \mathrm{H}$; but there was no significant difference between change in $\mathrm{PC}_{20} \mathrm{H}$ in subjects taking beclomethasone and those who were not? Possibly the administration of oral corticosteroids to seven subjects during the placebo period prevented fall in $\mathrm{PC}_{20}$ that would have resulted in a significan $\mathrm{N}$ difference between mean $\mathrm{PC}_{20} \mathrm{H}$ values for th民 cromoglycate and placebo periods. Omission of the data for these subjects, however, does not result in different outcome for $\mathbf{P C}_{20} \mathrm{H}$ change. Indeed, ora corticosteroids may not result in an improvement is non-specific airway reactivity except at very hig doses. $^{12}$ Finally, fluctuations in baseline lung function could possibly have contributed to the lack of change in $\mathrm{PC}_{20} \mathrm{H}$ during active treatment; but. analysis of $\mathrm{PC}_{20} \mathrm{H}$ values after exclusion of a subjects with a greater than $10 \%$ variability i baseline $\mathrm{FEV}_{1}$ did not alter the outcome of the study Several studies have documented a change in $\mathrm{PC}_{20} \mathrm{P}$ despite stable lung function. ${ }^{361112}$ Although the level of airways obstruction has a significant but in most studies ${ }^{2633}$ weak relationship to non-specifie responsiveness, it is probably not the majos determinant of such responsiveness in asthma.

The results of the study show that the. administration of sodium cromoglycate to subjectss with chronic, stable asthma did not alter non-specifie responsiveness to histamine during 16 weeks. $\mathrm{PC}_{20} \mathrm{I}$ 积 did not change in subjects whose lung functioß improved significantly.

This work was supported by a grant from the Department of Veterans' Affairs, New South Wales We thank Fisons Ltd (UK and Australia) for the provision of sodium cromoglycate and placeb@ spincaps and spinhalers and for supervision o\$ treatment randomisation. 


\section{References}

1 Cockcroft DW, Killian DN, Mellon JJA, Hargreave FE. Protective effect of drugs on histamine-induced asthma. Thorax 1977;32:429-37.

2 Nogrady SG, Bevan C. Inhaled antihistaminesbronchondilation and effects on histamine-and methacholine-induced bronchoconstriction. Thorax 1978;33:700-4.

3 Casterline CL, Evans R, Ward GW. The effect of atropine and albuterol aerosols on the human bronchial response to histamine. $J$ Allergy Clin Immunol 1976;58:607-13.

4 Peel ET, Gibson GJ. Effects of long-term inhaled sulbutamol therapy on the provocation of asthma by histamine. Am Rev Respir Dis 1980;121:973-8.

5 Ruffin RE, Cockcroft DW, Hargreave FE. A comparison of the protective effect of fenoterol and Sch 1000 on allergen-induced asthma. J Allergy Clin Immunol 1978;61:42-7.

6 Bandouvakis J, Cartier A, Roberts R, Ryan G, Hargreave FE. The effect of ipratropium and fenoterol on methacholine- and histamine-induced bronchoconstriction. Br J Dis Chest 1981;75:295-305.

7 Harvey JE, Tattersfield AE. Airway response to salbutamol: effect of regular salbutamol inhalations in normal, atropic and asthmatic subjects. Thorax 1982;37:280-7.

8 Altounyan REC. Changes in histamine and atropine responsiveness as a guide to diagnosis and evaluation of therapy in obstructive airways disease. In: Pepys $\mathbf{J}$, Frankland AW, eds. Disodium cromoglycate in allergic airways disease. London: Butterworths, 1970:47-53.

9 Dickson W. A one year's trial of Intal compound in 24 children with severe asthma. In: Pepys J, Frankland AW, eds. Disodium cromoglycate in allergic airways disease. London: Butterworths, 1970:105-19.

10 Griffin MP, MacDonald N, McFadden ER. Short and long-term effects of cromolyn sodium on the airway reactivity of asthmatics. $J$ Allergy Clin Immunol 1983;71:331-8.

11 Altounyan REC. Review of clinical activity and mode of action of sodium cromoglycate. Clin Allergy 1980;10 (suppl):481-9.

12 Ryan G, Latimer KM, Juniper EF, Roberts RS, Hargreave FE. Effect of beclomethasone on bronchial hyperresponsiveness in controlled, non-steroid dependent asthma. $J$ Allergy Clin Immunol 1985;75:25-30.

13 Snashall PD, Balwin C. Mechanisms of sulphur dioxide induced bronchoconstriction in normal and asthmatic man. Thorax 1982;37:118-23.

14 Harries MG, Parkes PEG, Lessof MH, Orr TSC. Role of bronchial irritant receptors in asthma. Lancet 1981;1:5-7.

15 Jackson DM, Richards IM. The effects of sodium cromoglycate on histamine aerosol-induced reflex bronchoconstriction in the anaesthetized dog. $\mathrm{Br} J$ Pharmacol 1977;61:257-62.

16 Woenne $R$, Kattan $M$, Levison $H$. Sodium cromoglycate-induced changes in the dose-response curve of inhaled methacholine and histamine asthmatic children. Am Rev Dis 1979;119:927-32.

17 Brompton Hospital-Medical Research Council Collaborative Trial. Long-term study of disodium cromoglycate in treatment of severe extrinsic or intrinsic bronchial asthma in adults. $\mathrm{Br}$ Med J 1972;iv:383-8.

18 Silverman M, Conolly NM, Balfour-Lynn L, Godrey S. Long-term trial of disodium cromoglycate and isoprenaline in children with asthma. $\mathrm{Br} \mathrm{Med} J$ 1972;iii:378-81.

19 Ryo UY, Kang B, Townley RG. Cromolyn therapy in patients with bronchial asthma. Effect on inhalation challenge with allergen, histamine and methacholine. JAMA 1976;236:927-31.

20 Kang B, Townley RG, Lee CK, Kolotkin BM. Bronchial reactivity to histamine before and after sodium cromoglycate in bronchial asthma. $\mathrm{Br} \mathrm{Med} J$ 1976;i:867-70.

21 Silverman M. Action of disodium cromoglycate. $\mathrm{Br} \mathrm{Med}$ J 1977; i:570.

22 Lemaire I, Cartier A, Malo JL, Pineau L, Shezzo H, Martin RR. Effect of sodium cromoglycate on histamine inhalation tests. J Allergy Clin Immunol 1984;73:234-9.

23 Spector SL, Chester EA, Hargreave FE, et al. Definition of Asthma. American Thoracic Society News 1982;fall:5.

24 Friedman M, Walker S. Assessment of lung function using an airflow-meter. Lancet 1975i:310-1.

25 Chai H, Farr RS, Froehlich LA, et al. Standardisation of bronchial inhalation challenge procedures. J Allergy Clin Immunol 1975;36:323-7.

26 Cockcroft DW, Killian DN, Mellon JJA, Hargreave FE. Bronchial reactivity to inhaled histamine: a method and clinical survey. Clin Allergy 1977;7:235-43.

27 Breslin FJ, McFadden ER, Ingram RH. The effects of cromolyn sodium on the airway response to hyperpnea and cold air in asthma. Am Rev Respir Dis 1980;122:11-6.

28 Patel KR, Berkin KW, Kerr JW. Dose-response study of sodium cromoglycate in exercise-induced asthma. Thorax 1982;37:663-6.

29 Lowhagen O, Rak S. Modification of bronchial hyperreactivity after treatment with sodium cromoglycate during pollen season. $J$ Allergy Clin Immunol 1985;75:460-7.

30 Rocchiccioli K, Pickering CAC, Cole M, Horsfield N. Effect of regular treatment with sodium cromoglycate on non-specific bronchial hyperreactivity [abstract]. Thorax 1984;39:706.

31 Juniper EF, Frith PA, Dunnett C, Cockcroft DN, Hargreave FE. Reproducibility and comparison of responses to inhaled histamine and methacholine. Thorax 1978;33:705-10.

32 Lowhagen O, Lindholm NB. Short-term and long-term variation in bronchial response to histamine in asthmatic patients. Eur J Respir Dis 1983;64:466-73.

33 Hargreave FE, Ryan G, Thomson NC, et al. Bronchial responsiveness to histamine or methacholine in asthma: measurement and clinical significance. $J$ Allergy Clin Immunol 1981;68:347-55. 